\title{
EDITORIAL
}

\section{Chicken or egg: physical activity in COPD revisited}

\author{
M.I. Polkey* and K.F. Rabe ${ }^{\#}$
}

(N) uietly, over recent years, a reassessment has occurred amongst those caring for patients with chronic obstructive pulmonary disease (COPD). Although COPD is triggered by the inhalation of noxious stimuli, usually cigarette smoke, it is now apparent that the condition has a significant extrapulmonary component [1]. COPD is of course diagnosed by the finding of a reduced forced expiratory volume in one second (FEV1); however, amongst patients with an FEV1 of $<50 \%$ predicted, FEV1 is a poor predictor of survival. What then does predict survival amongst patients with advanced disease? Certainly weakness of the principle locomotor muscle, the quadriceps, does [2], as does the reduction in quadriceps cross-sectional area [3]. It is also well established that exercise capacity, whether measured on a field test, as in the BODE (body mass index, airflow obstruction, dyspnoea, exercise capacity) score [4], or in the laboratory [5], is predictive of survival. Lastly, in large cohorts it is clear that self-reported physical activity predicts prognosis in COPD [6] and may even impact on the rate of lung function decline [7]. Indeed, recent data from 77,000 participants in the Nurses Health Study suggests that a lack of physical exercise is a major contributor to all causes of mortality irrespective of smoking history, although the latter is of course a separate and major risk factor [8].

Daily physical activity, muscle strength and performance are likely intimately interlinked; progress in the former area has been greatly advanced by the development of technology which permits physical activity monitoring. In its earliest guise, this could be as simple as a pedometer [9] or an actigraph [10]. However, most investigators prefer the more sophisticated devices now available, which can also give data on movement intensity and body posture. In direct comparison, these technologies are shown to be significantly more accurate than patient recall for the assessment of daily activity [11] and, as expected, early studies confirmed that patients with advanced disease were more inactive than age matched controls [12]. Except in very large epidemiologic studies, objective measurement of physical activity is likely to represent the gold standard tool in the future.

In patients with COPD, skeletal muscle weakness may lead to a downward disease spiral [13] in which anaerobic metabolism

*Royal Brompton Hospital and National Heart and Lung Institute, London, UK. ${ }^{*}$ Dept of Respiratory Medicine, University of Leiden, Leiden, The Netherlands.

STATEMENT OF INTEREST: Statements of interest for both authors of this manuscript can be found at www.erj.ersjournals.com/misc/statements.shtml

CORRESPONDENCE: M.I. Polkey, Royal Brompton Hospital and National Heart and Lung Institute, London SW3 6NP, UK. Fax: 44 2073518939. E-mail: m.polkey@rbht.nhs.uk and quadriceps fatigue during exercise lead to reduced mobility. This is likely exaggerated by acute exacerbation; for example, DonALDSON et al. [14] have noted that time spent outdoors is reduced in the days preceding exacerbation and is reduced for up to 5 weeks afterwards. After admission with acute exacerbation, physical activity is greatly reduced (to a mean walking time of 6-7 $\mathrm{min} \cdot \mathrm{day}^{-1}$ ) and fails to recover, even at 1 month, to levels observed in stable outpatients with equally severe COPD [15]. Perhaps unsurprisingly muscle strength falls in the first week of hospital admission due to exacerbation of COPD [16], and is moderately correlated with the degree of immobility [15]. A similar pattern is observed following admission with medical conditions associated with immobility, such as stroke [17].

Pulmonary rehabilitation (PR) is known to be a highly effective treatment in COPD [18]. PR has at best modest effects on lung function yet this therapy yields significant improvements in quadriceps strength [19] as well as a reduction in the susceptibility of the patient to sustain quadriceps fatigue while exercising [20]. Importantly, PR given soon after acute exacerbation reduces attendance at accident and emergency departments [21] and is associated with increased quadriceps strength [22]. Until recently it was largely unknown whether the increased exercise capacity conferred by rehabilitation resulted in an actual increase in physical activity of the patient. An important recently published study by PITTA et al. [23] suggests that while exercise capacity and quadriceps strength increase after a 3 month period of PR, daily physical activity does not. However, when the same patients were studied after an additional 3 months rehabilitation (i.e. 6 months in total) daily physical activity had significantly increased even though 6-min walk distance did not leading to the "Leuven concept" that one needs 3 months to train the muscle, but 6 months to train the brain.

In the context of a changing understanding of COPD as a disease with multiple comorbidities and potential systemic consequences, it is more than appropriate to critically assess whether reduced physical activity is the main driver of muscle weakness in COPD or whether the reverse is true. Certainly the historical view has been that muscle weakness might be a consequence of systemic inflammation [24] via the mechanism of generalised muscle atrophy and that physical performance is reduced as a consequence. However, this increasingly seems a less likely hypothesis, at least when it comes to quadriceps force. First, muscle weakness usually precedes cachexia; in the two largest studies quadriceps weakness was present in around a third of patients whereas nutritional depletion judged by bioimpedence was reduced in around two thirds $[25,26]$. Secondly, muscle weakness in COPD has a very 
regional distribution with sparing of the diaphragm [27], abdominal muscles [28] and upper limb muscles [29], which argues against a systemic cause. Thirdly, the changes observed in biopsies taken from the diaphragm [30,31] and deltoid [32] do not show the appearances typical of the quadriceps in COPD, again arguing against a systemic cause. Lastly, when directly examined, inflammatory cytokine expression in the quadriceps of patients with COPD is either absent [33] or correlates negatively with quadriceps weakness [34].

We therefore return to the reverse hypothesis, that reduced physical activity is an early feature of COPD. In this issue of the European Respiratory Journal and in their prior publication, WATZ and co-workers [35, 36] have greatly advanced our understanding of this field. By studying a large number of patients with a range of COPD severity they have been able to show that there is a progressive reduction in physical activity across the Global Initiative for Chronic Obstructive Lung Disease (GOLD) stages. In their first study [36], this observation was linked to measures of inflammation. Importantly inflammation assessed as highly sensitive C-reactive protein did not show a consistent trend across GOLD categories whilst fibrinogen wielded only a weak effect on physical activity (accounting for $9 \%$ of the variance of the steps taken per day) and handgrip strength, considered as a marker of systemic muscle strength also failed to show a consistent variation across GOLD stages. This study was weakened by not having a control group. In their present study [35], data were added from a group of patients who would formerly have been called GOLD stage 0 but in this study are termed chronic bronchitis in line with current convention. The study makes several interesting observations. First, with the exception of GOLD grade IV patients, physical activity was reduced on Sundays and public holidays. Secondly, a statistically significant reduction in aspects of physical activity was observed, compared with the chronic bronchitis patients, for patients with a BODE 1 score or for Medical Research Council grade 1 dyspnoea. These data strongly suggest that reduced physical activity has a behavioural component; i.e. that the patients are choosing to reduce their activity rather than having it imposed on them by pulmonary limitation.

Like any paper the data have some limitations; a weakness of both of these studies is the absence of data from true control subjects without any prior connection to the hospital or indeed of lifelong nonsmokers. This is important because it may be that smokers with normal spirometry who present to hospital are in some way self-selected. It is estimated that approximately half of chronic obstructive pulmonary disease patients are presently undiagnosed [37] and case finding studies in the community would be required to resolve this issue. It is also important because recent data suggest that smoking per se may induce oxidative stress in peripheral muscle [38]; WATZ and coworkers $[35,36]$ did not measure quadriceps strength in their subjects but a plausible hypothesis would be that quadriceps weakness due to immobility may be part of the lifestyle associated with smoking and may play a part in initiating the downward cycle of disability associated with chronic obstructive pulmonary disease. If this were the case simple interventions, such as encouraging gym membership, combined, where applicable, with tobacco cessation, may prove in the future to be a valuable strategy in the management and, although this is clearly more speculative, prevention of chronic obstructive pulmonary disease progression.

\section{REFERENCES}

1 Fabbri LM, Luppi F, Beghe B, Rabe KF. Complex chronic comorbidities of COPD. Eur Respir J 2008; 31: 204-212.

2 Swallow EB, Reyes D, Hopkinson NS, et al. Quadriceps strength predicts mortality in patients with moderate to severe chronic obstructive pulmonary disease. Thorax 2007; 62: 115-120.

3 Marquis K, Debigare R, Lacasse Y, et al. Midthigh muscle cross-sectional area is a better predictor of mortality than body mass index in patients with chronic obstructive pulmonary disease. Am J Respir Crit Care Med 2002; 166: 809-813.

4 Celli BR, Cote CG, Marin JM, et al. The body-mass index, airflow obstruction, dyspnea, and exercise capacity index in chronic obstructive pulmonary disease. N Engl J Med 2004; 350: 1005-1012.

5 Oga T, Nishimura K, Tsukino M, Sato S, Hajiro T. Analysis of the factors related to mortality in chronic obstructive pulmonary disease: role of exercise capacity and health status. Am J Respir Crit Care Med 2003; 167: 544-549.

6 Garcia-Aymerich J, Lange P, Benet M, Schnohr P, Anto JM. Regular physical activity reduces hospital admission and mortality in chronic obstructive pulmonary disease: a population based cohort study. Thorax 2006; 61: 772-778.

7 Garcia-Aymerich J, Lange P, Benet M, Schnohr P, Anto JM. Regular physical activity modifies smoking-related lung function decline and reduces risk of chronic obstructive pulmonary disease: a population-based cohort study. Am J Respir Crit Care Med 2007; 175: 458-463.

8 van Dam RM, Li T, Spiegelman D, Franco OH, Hu FB. Combined impact of lifestyle factors on mortality: prospective cohort study in US women. BMJ 2008; 337: a1440.

9 Schonhofer B, Ardes P, Geibel M, Kohler D, Jones PW. Evaluation of a movement detector to measure daily activity in patients with chronic lung disease. Eur Respir J 1997; 10: 2814-2819.

10 Walker PP, Burnett A, Flavahan PW, Calverley PM. Lower limb activity and its determinants in COPD. Thorax 2008; 63: 683-689.

11 Pitta F, Troosters T, Spruit MA, Decramer M, Gosselink R. Validation of a triaxial accelerometer to assess various activities in COPD patients. Am J Respir Crit Care Med 2004; 169: A594.

12 Pitta F, Troosters T, Spruit MA, Probst VS, Decramer M, Gosselink R. Characteristics of physical activities in daily life in chronic obstructive pulmonary disease. Am J Respir Crit Care Med 2005; 171: 972-977.

13 Polkey MI, Moxham J. Attacking the disease spiral in chronic obstructive pulmonary disease. Clin Med 2006; 6: 190-196.

14 Donaldson GC, Wilkinson TM, Hurst JR, Perera WR, Wedzicha JA. Exacerbations and time spent outdoors in chronic obstructive pulmonary disease. Am J Respir Crit Care Med 2005; 171: 446-452.

15 Pitta F, Troosters T, Probst VS, Spruit MA, Decramer M, Gosselink R. Physical activity and hospitalization for exacerbation of COPD. Chest 2006; 129: 536-544. 
16 Spruit MA, Gosselink R, Troosters T, et al. Muscle force during an acute exacerbation in hospitalised patients with COPD and its relationship with CXCL8 and IGF-I. Thorax 2003; 58: 752-756.

17 Harris ML, Polkey MI, Bath PM, Moxham J. Quadriceps muscle weakness following acute hemiplegic stroke. Clin Rehabil 2001; 15: 274-281.

18 Griffiths TL, Burr ML, Campbell IA, et al. Results at 1 year of outpatient multidisciplinary pulmonary rehabilitation: a randomised controlled trial. Lancet 2000; 355: 362-368.

19 Bernard S, Whittom F, Leblanc P, et al. Aerobic and strength training in patients with chronic obstructive pulmonary disease. Am J Respir Crit Care Med 1999; 159: 896-901.

20 Mador MJ, Kufel TJ, Pineda LA, et al. Effect of pulmonary rehabilitation on quadriceps fatiguability during exercise. Am J Respir Crit Care Med 2001; 163: 930-935.

21 Man WD, Polkey MI, Donaldson N, Gray BJ, Moxham J. Community pulmonary rehabilitation after hospitalisation for acute exacerbations of chronic obstructive pulmonary disease: randomised controlled study. BMJ 2004; 329: 1209.

22 Seymour J, Ward C, Jolley C, et al. Effect of early pulmonary rehabilitation (PR) on quadriceps strength and fat-free mass following hospital admission for acute COPD exacerbation. Eur Respir J 2007; 30: Suppl. 51, 94 S.

23 Pitta F, Takaki MY, Oliveira NH, et al. Relationship between pulmonary function and physical activity in daily life in patients with COPD. Respir Med 2008; 102: 1203-1207.

24 Debigare $\mathrm{R}$, Marquis $\mathrm{K}$, Cote $\mathrm{CH}$, et al. Catabolic/anabolic balance and muscle wasting in patients with COPD. Chest 2003; 124: 83-89.

25 Hopkinson NS, Tennant RC, Dayer MJ, et al. A prospective study of decline in fat free mass and skeletal muscle strength in chronic obstructive pulmonary disease. Respir Res 2007; 8: 25.

26 Franssen FM, Broekhuizen R, Janssen PP, Wouters EF, Schols AM. Limb muscle dysfunction in COPD: effects of muscle wasting and exercise training. Med Sci Sports Exerc 2005; 37: 2-9.

27 Polkey MI, Kyroussis D, Hamnegard C-H, Mills GH, Green M, Moxham J. Diaphragm strength in chronic obstructive pulmonary disease. Am J Respir Crit Care Med 1996; 154: 1310-1317.

28 Man WD, Hopkinson NS, Harraf F, Nikoletou D, Polkey MI, Moxham J. Abdominal muscle and quadriceps strength in chronic obstructive pulmonary disease. Thorax 2005; 60: 718-722.

29 Man WD, Soliman MG, Nikoletou D, et al. Non-volitional assessment of skeletal muscle strength in patients with chronic obstructive pulmonary disease. Thorax 2003; 58: 665-669.

30 Levine S, Kaiser L, Leferovich J, Tikunov B. Cellular adaptations in the diaphragm in chronic obstructive pulmonary disease. N Engl J Med 1997; 337: 1799-1806.

31 Stubbings AK, Moore AJ, Dusmet M, et al. Physiological properties of human diaphragm muscle fibres and the effect of chronic obstructive pulmonary disease. J Physiol 2008; 586: 2637-2650

32 Gea JG, Pasto M, Carmona MA, Orozco-Levi M, Palomeque J, Broquetas J. Metabolic characteristics of the deltoid muscle in patients with chronic obstructive pulmonary disease. Eur Respir J 2001; 17: 939-945.

33 Crul T, Spruit MA, Gayan-Ramirez G, et al. Markers of inflammation and disuse in vastus lateralis of chronic obstructive pulmonary disease patients. Eur J Clin Invest 2007; 37: 897-904.

34 Barreiro E, Schols AM, Polkey MI, et al. Cytokine profile in quadriceps muscles of patients with severe COPD. Thorax 2008; 63: 100-107.

35 Watz H, Waschki B, Meyer T, Magnussen H. Physical activity in patients with COPD. Eur Respir J 2009; 33: 262-272.

36 Watz H, Waschki B, Boehme C, Claussen M, Meyer T, Magnussen H. Extrapulmonary effects of chronic obstructive pulmonary disease on physical activity: a cross-sectional study. Am J Respir Crit Care Med 2008; 177: 743-751.

37 Rabe KF, Hurd S, Anzueto A, et al. Global strategy for the diagnosis, management, and prevention of chronic obstructive pulmonary disease: GOLD executive summary. Am J Respir Crit Care Med 2007; 176: 532-555.

38 Montes de Oca M, Loeb E, Torres SH, De Sanctis J, Hernandez N, Talamo C. Peripheral muscle alterations in non-COPD smokers. Chest 2008; 133: 13-18. 